\title{
GEORG HENRIKSEN
}

\section{FELLESSKAPETS SAMMENBRUDD OG KOLLEKTIV SMERTE}

Denne artikkelen handler om samfunn som fellesskap og individets forhold til fellesskapet. ${ }^{1}$ Den handler om den smerte som menneskene erfarer når de ser seg selv, de andre og hele sitt samfunn gå i oppløsning. En slik destruktiv prosess kan vi finne når sosiale grupper eller hele samfunn blir marginalisert i forhold til et sentrum som utøver direkte eller indirekte makt, ikke sjelden med katastrofale konsekvenser for befolkningens psykiske og fysiske helse. Når et fellesskap går i oppløsning vil det enkelte individ kunne komme til å leve i et limbo hvor tilværelsen tømmes for sammenheng og mening. Når dette vedvarer vil individet oppleve tap av retning og fremtid i livet, og oppleve en eksistensiell smerte; en smerte som forsterkes ved at de andre som individet vender seg til opplever tilsvarende smerte. På samme måte som den enkeltes opplevelse av glede ofte øker når den deles med andre som har den samme opplevelsen, vil den eksistensielle smerte forsterkes når den samtidig er et kollektivt fenomen. Jeg vil derfor snakke om en felles, delt smerte som et fenomen, og hevde at det er et gjensidig forhold mellom denne og individets eksistensielle smerte, og at dette forholdet kan lede til en selvforsterkende og ødeleggende prosess for individ og samfunn.

Siden 1966 har jeg fulgt et lite indianersamfunn i Canada som har gjennomgått en slik dramatisk utvikling. I løpet av disse årene møtte jeg en lege som opplevet sitt arbeid som nær meningsløst fordi han ikke kunne gjøre annet enn midlertidig å bøte på den enkelte pasients lidelser. Han innså nødvendigheten av å endre de politiske rammebetingelsene som myndighetene har lagt for indianerne og deres samfunn, men uten at myndighetene har ført noen av hans synspunkter frem til handling.

Både for legen og sosialantropologen er det en utfordring å utforske sammenhengene mellom tre nivåer: individets opplevelse av lidelser og eksistensielle smerte, samfunnet som individet er en del av, og de videre politiske prosesser som blant annet nedfeller seg som muligheter og begrensninger for det enkelte menneske til å utvikle meningsfylte livsprosjekter (Giddens 1991; Scheper-Hughes 1992 og 1994). Men som Byron J. Good påpeker, er dette både en stor og meget vanskelig utfordring:

Jeg [...] påpeker den enorme vanskelighet ved dels å skrive om historisert erfaring, dels ved å vise hvordan politiske og økonomiske strukturer inngår i erfaring i likeså stor grad som tidlige familieerfaringer og biologi, og endelig ved å skildre disse problemstillinger i vår etnografiske og fortolkende form (Good 1992:200-201). 
Situasjonen jeg skal beskrive her er preget av at menneskene ikke lenger besitter adekvate modeller for fortolkning og handling i sin livsverden.

Konkret handler artikkelen om et indianersamfunn i Nord-Canada, om et folk som ekteskapet, sviktende omsorg for barna, sedelighetsforbrytelser, ungdomskriminalitet (men sjelden alvorlig), ulykker som skyldes alkoholbruken, ofte med døden til følge, og en skremmende selvmordsstatistikk. Fra 1991 til 1993 var det, av en befolkning på 460 personer, 203 personer som forsøkte å ta sine liv. Bare i løpet seks måneder i 1993 forsøkte 90 personer å ta sine liv (Rich 1994). Dette er alle selvmordsforsøk hvor andre innu måtte gripe inn for å hindre fullbyrdelse, og hvor medisinsk behandling også var nødvendig i de fleste tilfeller.

Davis Inlet nådde verdenspressen i 1993 da seks innu barn ble funnet $\mathrm{i}$ et skur uten varmekilde. Det var i januar og temperaturen var $-40^{\circ}$. Barna sniffet bensin og skrek at de ville dø, og at de ikke ønsket å bli reddet. Året før omkom seks barn i en husbrann etter at foreldrene forlot dem for å gå på fylla.

Når et samfunn brytes ned og når en slik katastrofal tilstand, overskrides en terskel hvor en felles, delt smerte blir et fenomen, og hvor individets eksistensielle smerte forsterkes av den felles, delte smerte de alle lider under. Slik kollektiv smerte inntrer når den enkelte ikke kan vende seg til andre uten at han/hun møtes av at alle lider under tilsvarende smerte som dem selv. Over alt ser de lidelser i hverandres ansikter, i kroppens bevegelser, i øynene. I Davis Inlet har innu nådd et stadium hvor de sier vi er i ferd med å gå til grunne som et samfunn og som bærere av en kultur. Angsten og smerten som følger av at de hverken som individer eller som et kollektiv mestrer sine liv, fører til utstrakt bruk av alkohol og vold mot en selv og andre. Både individer, relasjoner og samfunn er viklet inn i en selvdestruktiv, apokalyptisk prosess.

Jeg har sett så mange tragedier før vi mistet barna i brannen. Hver gang det dør noen er det på grunn av alkohol. Alkohol er et stort problem. Det skjer selvmord, ulykker og drap. De gamle drikker for mye, også fordi vi er likeglade og ikke lytter til dem. Vi hører ikke på dem fordi vi drikker for mye, og vi passer ikke på barna våre. Hva som helst kan hende oss når som helst. (Gathering Voices 1992:4). ${ }^{2}$

Selv de få som ikke drikker opplever og deler lidelsene. Dette sier en av de eldre i Davis Inlet:

Jeg drikker ikke, men når det blir drukket $\mathrm{i}$ landsbyen blir jeg trett. Det skyldes angsten for hvordan fylla påvirker livet $\mathrm{i}$ landsbyen. (Op.cit.:4).

Hvordan skal vi forklare denne eksistensielle smerte?

\section{Fra fellesskap til marginalitet: fremveksten av eksistensiell smerte}

Fra en nomadisk tilværelse som villreinjegere i telt, ble innu i løpet av kort tid da myndighetene 1967 begynte byggingen av en landsby til dem, med boliger, skole, butikk, helsestajon og et dieselaggregat for levering av strøm. Savnet av livet og rytmen i jaktleirene i innlandet, av fellesskapet knyttet til dette og til jakten, var inn til margen gjennomtrengende. Alle gir de uttrykk for en intens opplevelse av å ha tapt meningsfylde i sin til- 
værelse. Samtidig er det en voksende erkjennelse av at deres språk og kultur trues ettersom barna må sitte på skolebenken i stedet for å lære ferdighetene som jegerfolk.

Innu forlot en tilpasning og en samfunnsorden som ga dem rik anledning til å feire hverandre. Gjennom alle dagliglivets handlinger realiserte hver enkelt innu sine potensialer i et økonomisk, sosialt og moralsk fellesskap som fungerte uavhengig av statlige institusjoner og andre eksterne mekanismer for sosial integrasjon (Henriksen 1973). Slik bidro alle til å vedlikeholde det fellesskapet som samtidig fylte den enkeltes handlinger med moralsk innhold og mening. Folk var bundet til hverandre gjennom komplekse, sammensatte bånd med instrumentelle, rituelle, og moralske dimensjoner med stor gjennomslagskraft. Bakt inn i disse bånd lå det entydige instrukser om gode og riktige handlinger, og hva som ville bli sanksjonert av fellesskapet. Gjennom en rekke større og mindre ritualer ble sentrale verdier kommunisert. Slik ble innu ansvarliggjort overfor hverandre, og sosial integrasjon fulgte som en uintendert konsekvens. Det var dette fellesskapet, og forbindelsen mellom det og den enkelte innus handlinger, som i løpet av en håndfull år raste sammen. Blant annet gjennom tvungen skolegang og fast bosetting skulle innu inkorporeres i det hvite samfunn og bli en del av det moderne Canada.

Men samtidig som Innu tapte sin sosiale og moralske orden, forble de ytterst marginale i forhold til det hvite samfunn. Det ble ikke gjort noe fors $ø \mathrm{k}$ fra statens side på å fylle de nye virksomhetsområder med mening. Tvert i mot: skolen hadde hvite lærere som bare snakket engelsk. Ingenting i pensum reflekterte innus kultur og livsform. Den katolske kirken anerkjente ikke deres egen religion som er høyst levende for dem. Med andre ord, det hvite samfunns institusjoner har kolonialisert alle innus livsområder, og dette uten å vise anerkjennelse og respekt for indianerne, deres samfunn og kultur. Samtidig er innu satt i en situasjon, økonomisk og politisk, som gir få eller ingen muligheter for det enkelte menneske og det enkelte hushold til å disponere sin arbeidskraft, til å planlegge sin fremtid, hverken på kort eller lang sikt. Innu er satt i en angstskapende situasjon hvor de ikke lenger har kulturelle modeller som strekker til for å tolke og handle i forhold til realitetene. Dermed har de vanskeligheter med å se en meningsfylt fremtid både for seg selv og barna. I enkelte tilfeller har dette ført til en katastrofal svikt i omsorgen for barna (Chisholm 1992).

Livet i landsbyen fremstod for dem alle som meningsløst, i kontrast til det livet de førte som jegere i innlandet. I dag bærer de sine problemer og sine lidelser med seg også til innlandet:

Selv når vi er i innlandet har folk stadig problemer. De har så mye smerte inne i seg at innlandet ikke er nok til å hjelpe dem. Selv i innlandet sniffer barna av og til. En person prøvde til og med å begå selvmord mens han var i innlandet. Folk har stadig bruk for behandling. Folk beholder smerten inne i seg, de viser den ikke. Jeg har mye smerte inne i meg nå. Hvis jeg drar til innlandet vil jeg være lykkelig der, men problemerne vil stadig være inne i meg. Det er som at flykte fra problemerne i stedet for å ordne opp i dem (Gathering Voices 1993:59).

\section{Redsel for ensomhet}

Mushuau innu har alltid stått opp med sola for å gå på jakt. De står fremdeles opp med sola, men i den landsbyen som de hvite bygget for dem på slutten av 60-tallet står de opp 
for å gå sine runder fra hus til hus og fra beger til beger. Midt på dagen sover de ut rusen, før de begynner på nytt om kvelden.

Innu opplever ensomhet fordi de ikke når hverandre etter at fellesskapet ble borte. Alkoholen og drikkelagene skaper nok en viss grad av fellesskap. Men dette fellesskapet er begrenset til nettverk og klikker, noe som begrenser dets evne til å gi meningsinnhold til handlinger og relasjoner. Situasjonen i innus jegersamfunn var annerledes. Her spilte det ingen rolle hvilken jaktleir du kom til: fellesskapet $\mathrm{i}$ handlinger knyttet til jakten omfattet alle innu, og ladet sosiale bånd med et innhold som var allmennt omsettbart hvor du enn kom.

Alkohol spiller også en hovedrolle i nedbrytningen av våre liv. Folk stoler ikke på hverandre lenger. Vi faller fra hverandre. Folk snakker ikke sammen nå. Før var det en mer vennlig atmosfære. Vi har for stor avstand til hverandre og kan ikke lenger hjelpe hverandre (Gathering Voices 1993:55).

Innu frykter ensomhet. For en innu er det å bli ensom det verste som kan skje et menneske, og spesielt den ensomhet som oppleves når et medlem av familien, slekt eller venner dør. Da er det ikke bare de gjenlevende som er ensomme, men de døde opplever også ensomhet, og lengter etter at de levende skal følge dem. Da en av mine gamle venner mistet sin kone, sa han til sin bror at nå ville han også dø. Han døde noen måneder senere i fylla - kvalt i sitt eget oppkast.

For å forstå den høye selvmordsraten blant innu må vi derfor vite noe om hvordan de oppfatter døden og det de kaller ensomhet, fordi slike oppfatninger danner kulturelle modeller både for fortolkning og handling. På mine turer i det indre av Labrador ga Pishum, en av de eldre indianerne jeg kjente, uttrykk for sin ensomhet hver gang vi passerte en gammel leirplass som var blitt brukt av en avdød person som stod ham nær. Ikke bare ensomhet, men lengsel etter å følge etter den døde.

Når ensomheten og lengselen etter de døde blir for sterk, fastholder indianerne at de kan bestemme seg for å dø, og at de ikke er redde for å dø. Slik bestemte Pishum seg for å dø da hans bror og hans kone og fem av deres barn druknet under en båttur på vei til jaktmarkene. I likhet med så mange andre ulykker som rammer innu skyldtes det at foreldrene hadde drukket alkohol. I Davis Inlet var Pishum en av de svært få som ikke drakk.

Etter en lengre periode hvor han var svært nedtrykt, bestemte han seg likevel for å leve videre for sine to barn og barnebarns skyld. Noen år senere ble han vitne til at en av hans døtre og hennes mann, begge sterkt beruset, druknet da kanoen de satt i veltet. Igjen bestemte'Pishum seg for å dø. Han sluttet å spise og havnet til slutt på sykehus lenger sør i Labrador. Her ble han holdt i live ved hjelp av intravenøs næring. Fra å være en kraftig mann veiet han til slutt bare $36 \mathrm{~kg}$. Legene hadde gitt ham opp da hans eldste dattersønn kom med cariboukjøtt og overtalte ham til å leve videre.

Pishum fortalte at da han fikk datteren i land var hun fremdeles i live. „Hun døde i armene mine der på stranden. Hadde det bare vært en hvit person tilstede så hadde hun kanskje blitt reddet“, sa han. „For jeg visste ikke hva jeg skulle gjøre.“ På en fortettet måte er dette uttrykk for den avmakt innu opplever. Den største smerten er knyttet til nettopp det at de ser seg selv, samfunnet og sin kultur gå til grunne uten at de er i stand til å gjøre noe med det. Selvom Pishum ikke drakk, kjente han den samme smerten som førte hans datter og svigersønn inn i det dødbringende alkoholkonsumet. Til denne gordiske knuten hører også den ydmykelsen som følger av at de hvite har maktstjålet dem. Innu ser det slik at det først og fremst er de hvite som har satt dem i en situasjon hvor de 
ikke lenger mestrer sine liv og frykter at de ikke lenger kan forvalte sin egen kultur, samtidig som de erkjenner sin avhengighet av de institusjoner som de hvite forvalter. De innser at de må tilegne seg en mengde nye ferdigheter fra de hvite for å hamle opp med den situasjonen som de befinner seg i. Samtidig ser de at barn og barnebarn i stadig sterkere grad blir suget inn i et konsummønster som de oppfatter som uforenlig med innu kultur og livsførsel - et konsummønster som binder dem til landsbyen, butikken og fjernsynsskjermen.

For innu fremstår alle disse faktorer og uforenlige hensyn og behov som en uløselig knute, og denne blir ytterligere smertefull ved at så mange har internalisert de hvites negative stereotypier om innu.

\section{Strukturell vold}

Innus oppfatning av ensomhet og død blir, sammen med alkoholbruken og den strukturelle vold de utsettes for, del av en selvforsterkende ond sirkel som fører til innus eksistensielle og kollektive smerte.

Mushuau innu er eksempel på en urbefolkning som ikke er utsatt for organisert vold fra myndighetenes side, men derimot vold som følge av mangel på adekvate tiltak for å hindre sosio-kulturelt sammenbrudd i Innus samfunn. Volden innusamfunnet rammes av har sin bakgrunn i de kanadiske myndigheters økonomiske og politiske beslutninger som treffes i storsamfunnets tro på utvikling og integrasjon via innlemmelse. På tross av den makt staten har, dens suverenitetsutøvelse, og koplet med - eller fordi den styres etter - en ideologi som ikke gir rom for alternative utviklingsretninger for urfolk, legger den ikke vekt på å utvikle de institusjoner, ritualer og symboler som er nødvendige for å inkorporere urfolkene i „det sivile samfunn“ (the civil society). Dermed opplever ikke innu at staten ansvarliggjør seg overfor dem, og de opplever statens utøvelse av makt som illegitim.

I likhet med sosialantropolgen, kom også legen, som jeg nevnte innledningsvis, til den konklusjon at skal innus fysiske lidelser og eksistensielle smerte reduseres, så må myndighetene sørge for å bringe til opphør den strukturelle vold. Den politikk som har vært ført hittil, og som til dels har bestått av mangelen på en politikk, må erstattes av et politisk og sosialt rom hvor innu kan utvikle adekvate kulturelle modeller til fortolkning av sine problemer, og at deres fortolkninger og syn på mulige løsninger bygges inn som premisser i myndighetenes politikk; ja som til og med kan gi muligheter for et innu selvstyre på viktige områder. Bare slik kan de finne veien ut av sin smertefulle, anomiske situasjon, og i stedet skape mening og kontroll i sine liv.

\section{Noter}

1. Artikkelen bygger blant annet på materiale samlet inn ved hjelp av bevilgning fra NAVF, Delprosjekt Miljø og Utvikling: 550.88/013. Takk til John Chr. Knudsen og Edvard Hviding for kommentarer.

2. Etter brannen hvor seks barn omkom, fortalte høvdingen meg at redselen for det som skjer med samfunnet deres, og som fører til at så mange lider en tragisk død, fikk noen av de unge til å stanse alkoholkonsumet og ta et lederskap i landsbyen. Noe av det første de gjorde var å skrive ned hva folk ville fortelle om hvor- 
dan de opplever sin situasjon og sitt forhold til de hvite institusjoner. Som et rop til myndighetene er dette blitt til to publikasjoner: Gathering Voices: Finding Strenght to Help Our Children, 1992 og Gathering Voices: Discovering our Past, Present and Future, 1993.

\section{Litteratur}

Chisholm, James S.

$1992 \quad$ Putting people in biology: toward a synthesis of biological and psychological anthropology. I: T. Schwartz, G.M. White \& C. Lutz (eds.): New directions in psychological anthropology. Cambridge: Cambridge U.P.

Innu Nation and the Mushuau Innu Band Council

$1992 \quad$ Gathering Voices: Finding Strength to Help Our Children. Ntesinan.

1993 Gathering Voices: Discovering Our Past, Present and Future. Ntesinan.

Giddens, Anthony

1991 Modernity and Self-Identity: Self and Society in the Late Modern Age. Oxford: Polity Press.

Good, Byron J.

1992 Culture and psychopathology: directions for psyciatric anthropology. I: T. Schwartz, G.M.

White \& C. Lutz (eds.): New directions in psychological anthropology. Cambridge:

Cambridge U.P.

Henriksen, Georg

1973 Hunters in the Barrens. The Naskapi on the Edge of the White Man's World. St.John's: ISER, Memorial University of Newfoundland.

1993 Life and Death Among the Mushuau Innu of Northern Labrador. St.John's: ISER Research and Policy Papers No. 17, Memorial University of Newfoundland.

Rich, George

1994 Statement of the Innu People to the United Nations Human Rights Commission. IWGIA Newsletter. Copenhagen: IWGIA.

Scheper-Hughes, Nancy

1992 Hungry bodies, medicine, and the state: toward a critical psychological anthropology. I: T. Schwartz, G.M. White \& C.A. Lutz (eds.): New directions in psychological anthropology. Cambridge: Cambridge U.P.

1994 Embodied Knowledge: Thinking with the Body in Critical Medical Anthropology. I: R. Borofsky (ed.): Assessing Cultural Anthropology. McGraw-Hill. 